\title{
Originals
}

\section{Central role for sodium in the pathogenesis of blood pressure changes independent of angiotensin, aldosterone and catecholamines in Type 1 (insulin-dependent) diabetes mellitus}

\author{
B. Feldt-Rasmussen ${ }^{1}$, E. R. Mathiesen ${ }^{1}$, T. Deckert ${ }^{1}$, J. Giese ${ }^{2}$, N.J.Christensen ${ }^{3}$, L. Bent-Hansen ${ }^{1}$ and \\ M. D. Nielsen ${ }^{2}$ \\ ${ }^{1}$ Steno Memorial Hospital, Gentofte, ${ }^{2}$ Department of Clinical Physiology and Nuclear Medicine, Glostrup Hospital, Glostrup and \\ ${ }^{3}$ Department of Internal Medicine and Endocrinology, Herlev Hospital, Herlev, Denmark
}

\begin{abstract}
Summary. We studied 73 Type 1 (insulin-dependent) diabetic patients, 18 to 50 years of age, with a diabetes duration of more than five years. Group 1: normal urinary albumin excretion below $30 \mathrm{mg}$ per $24 \mathrm{~h}(n=19)$; group 2: microalbuminuria, $30-300 \mathrm{mg}$ per $24 \mathrm{~h}(n=36)$; and group 3: diabetic nephropathy, above $300 \mathrm{mg}$ per $24 \mathrm{~h}(n=18)$. Fifteen nondiabetic persons matched for sex and age served as control subjects. The sodium intake evaluated on the basis of $24-\mathrm{h}$ urine sodium excretion was similar in patients and control subjects. Blood pressure in groups 1 and 2 and control subjects was below $160 / 95 \mathrm{mmHg}$. The blood pressure was increased in group 3 as compared with the other groups (systolic/diastolic $161 \pm 22 / 101 \pm 9 \mathrm{mmHg}$ vs $131 \pm 13 / 84 \pm 10$, mean $\pm \mathrm{SD}, p<0.0001)$. Exchangeable sodium was increased in patients $(p<0.01)$ and correlated to the mean blood pressure $(n=70, r=0.41, p<0.01)$. Extracellular volume was increased in patients $(p<0.05)$, whereas plasma volume was
\end{abstract}

normal. Supine serum angiotensin II was suppressed in the patients $(p<0.001)$. A negative correlation was found between mean blood pressure and supine serum aldosterone ( $n=68, r=-0.24, p<0.05)$, and exchangeable sodium and aldosterone $(n=66, r=-0.36, p<0.002)$ in all patients. The catecholamine levels were also suppressed or normal in the patients. These data suggest that sodium retention plays a major role and that the aldosterone, angiotensin II and catecholamine levels are suppressed during the blood pressure rise observed in the very early stages of diabetic renal disease.

Key words: Type 1 (insulin-dependent) diabetes, urinary albumin excretion, exchangeable sodium, blood pressure, extracellular volume, plasma volume, catecholamines, renin, converting enzyme, angiotensin II.
In Type 1 diabetes mellitus the development of clinical diabetic nephropathy as demonstrated by the presence of more than $0.5 \mathrm{~g}$ total protein in 24-h urine is a serious prognostic marker [1-4]. The high relative mortality among Type 1 diabetic patients is mainly restricted to patients with proteinuria [5]. The etiology of diabetic nephropathy is unknown. Several observations indicate that an increasing blood pressure level may play an important role. First, blood pressure levels are significantly elevated in patients with microalbuminuria, i.e. Albustix-negative urine but slightly elevated urinary albumin excretion in the range of 30 to $300 \mathrm{mg}$ per $24 \mathrm{~h} \mathrm{[6-9].} \mathrm{These} \mathrm{patients} \mathrm{are} \mathrm{known} \mathrm{to} \mathrm{be} \mathrm{at} \mathrm{high}$ risk of developing diabetic nephropathy $[7,8,10,11]$. Second, this blood pressure rise is not present at the onset of diabetes. This was documented by the observation that the blood pressure level at onset of diabetes before the development of microalbuminuria was the same in patients who developed nephropathy as in those who survived their disease for more than
40 years [9]. Third, we recently demonstrated a significant positive correlation between the blood pressure rise and the annual changes in urinary albumin excretion in Type 1 diabetic patients with microalbuminuria [12]. Finally, antihypertensive treatment can reduce the progression rate of diabetic nephropathy $[13,14]$.

The mechanism behind hypertension in diabetes is poorly understood. Sodium retention may play a role $[15,16]$. However, studies of renin activity in heterogenous groups of diabetic patients have yielded conflicting results as to whether renin activity is high, normal or low [15-18]. Recently, plasma renin activity was reported normal in well characterised, uncomplicated long-term Type 1 diabetic patients [19], but elevated in patients with microvascular complications [20]. Only a few studies of small or heterogenous groups of diabetic patients have included measurements of angiotensin II and aldosterone, the effector components of the system; but they are described as normal in patients without, and low in patients with signs of diabetic neuropa- 
thy [21-24]. The catecholamine levels are also normal or depressed in Type 1 diabetes [25] except in rare cases with severe postural hypotension [26].

With this background we have studied blood pressure, exchangeable sodium, plasma volume and extracellular volume together with the renin-angiotensinaldosterone system (RAAS) and catecholamines in Type 1 diabetic patients with or without renal microangiopathic lesions of varying degree classified according to the urinary albumin excretion rate.

Our aim was to investigate possible pathophysiological mechanisms behind the development of arterial hypertension in diabetic renal disease.

\section{Subjects and methods}

\section{Subjects}

Seventy-three Type 1 diabetic patients with a diabetes duration of more than five years were studied. They had no history of non-diabetic renal or cardiac disease, and all had a negative bacterial culture of the urine. Fifteen healthy non-diabetic subjects matched for sex and age served as controls. All subjects gave informed consent for participation, and the study was approved by the Regional Scientific Ethics Committee. The patients were subdivided into three groups according to level of albuminuria identified on the basis of the median albumin excretion in three 24-h urine collections performed at home during normal physical activity. This was done in order to take into account the high $(50 \%)$ day to day variation of the 24 -h urinary albumin excretion [27]. Normal control subjects delivered one 24-h urine sample.

The three groups were defined as follows:

Group 1. Nineteen Type 1 patients with normal urinary albumin excretion, below $30 \mathrm{mg} / 24 \mathrm{~h}$, and with blood pressure below $160 / 95 \mathrm{mmHg}$.

Group 2. Thirty-six Type 1 patients with elevated urinary albumin excretion in the range of 30 to $300 \mathrm{mg} / 24 \mathrm{~h}$, i. e. patients with persistent microalbuminuria (incipient diabetic nephropathy). During the screening procedure aimed at establishing this group, patients with blood pressure readings above $160 / 95 \mathrm{mmHg}$ were excluded as previously described [28]. In our clinic blood pressure readings above $160 / 95 \mathrm{mmHg}$ were found in $7 \%$ of patients with incipient nephropathy.

Group 3. Eighteen Type 1 patients with diabetic nephropathy (urinary albumin excretion above $300 \mathrm{mg} / 24 \mathrm{~h}$ ). Any ongoing antihypertensive treatment had been discontinued for 8 weeks (five patients).

The clinical characteristics of patients and control subjects are shown in Table 1. A close match of sex distribution, age and diabetes duration was obtained.

\section{Study protocol}

All subjects continued on free sodium intake and no medication other than insulin was allowed. The investigations were carried out on two consecutive days, in the morning preceded by a normal breakfast and insulin injection at home. A cannula was inserted in the antecubital vein in each arm. The patients had rested for $60 \mathrm{~min}$ in the supine position, before any blood samples were drawn. On the first day all basal blood samples were drawn $(120 \mathrm{ml}$ of blood $)$ and then the tracers for measurement of plasma-volume and total exchangeable sodium were injected. Urine was collected at home during the following $24 \mathrm{~h}$ for measurement of urinary sodium excretion and of urinary loss of isotope to be compensated for when calculating exchangeable sodium. On the second day the glomerular filtration rate and extracellular volume were measured.

\section{Methods}

Urinary albumin concentration was measured by an ELISA assay; interassay variation was $8.3 \%$ [27].

Haemoglobin $A_{l c}$ was measured by a chromatographic technique [29]. The normal range was $4.1-6.4 \%$.

Blood pressure was measured with a standard sphygmomanometer (cuff, 25 by $12 \mathrm{~cm}$ ) on the right arm after 20 min of supine rest on both days. The diastolic blood pressure was recorded when the Korotkoff's sounds disappeared (phase V). Mean blood pressure was taken as diastolic $+1 / 3$ (systolic-diastolic) blood pressure.

Beat-to-beat variation as an index of autonomic neuropathy was assessed according to Ewing and Clark [30].

Plasma volume (PV, $\mathrm{ml} / 1.73 \mathrm{~m}^{2}$ ) was measured by a multiple sampling technique using ${ }^{125} \mathrm{I}$-labelled human serum albumin (Code IFA-IT23S, Kjeller, Oslo, Norway) [31].

Total exchangeable sodium (meq/1.73 $\mathrm{m}^{2}$ ) was measured using ${ }^{24} \mathrm{Na}$ (Code RIIS 1245, Risø, Denmark) [32].

The glomerular filtration rate $\left(\mathrm{ml} / \mathrm{min} \times 1.73 \mathrm{~m}^{2}\right)$ [33] and the extracellular fluid volume $\left(\mathrm{ml} / 1.73 \mathrm{~m}^{2}\right)$ [34] were measured after a single injection of ${ }^{51} \mathrm{Cr}$ EDTA (Hoechst, Frankfurt, FRG), plotting the plasma disappearance of the tracer from the third to the fourth hour.

Plasma concentrations of components of the renin-angiotensinaldosterone system were determined by radioimmunoassays as previously described: Renin substrate [35], active and inactive renin [36], angiotensin I [37], angiotensin II [38], aldosterone [39] and converting enzyme [40]. The plasma samples were isolated and stored at $-20^{\circ} \mathrm{C}$ until analysis. Across the study period stability of the various assays and samples was carefully controlled by analysis of pool samples together with patient samples. For angiotensin II the coefficient of variation between days for two different pools with mean concentration of $13 \mathrm{pg} / \mathrm{ml}$ and $15 \mathrm{pg} / \mathrm{ml}$ plasma was found to be $13.9 \%$ $(n=34)$ and $9.3 \%(n=31)$ over periods of 6 and 7 months respectively. All angiotensin II samples from these patients and control subjects were analysed within 5 months from the time where the blood samples were taken. For aldosterone similar studies showed a coefficient of variation of a pool with a mean concentration of $9 \mathrm{ng}$ / $100 \mathrm{ml}$ plasma of $12.7 \%(n=17)$ over 5 months and $12.4 \%(n=31)$ over 9 months. The day to day variation for measurement of renin concentration was $8 \%$. Angiotensin I measurements were evaluated by sample to sample variation and this was found to be $16 \%$.

The sensitivity of the assays was as follows: angiotensin II: $2 \mathrm{pg} /$ $\mathrm{ml}$ plasma, angiotensin $\mathrm{I}: 3 \mathrm{pg} / \mathrm{ml}$ plasma and aldosterone: $0.5 \mathrm{ng}$ / $100 \mathrm{ml}$ plasma. These concentrations produced a significant decrease in percentage of binding of tracer to antibody.

Our analytical methods for determination of angiotensin II, angiotensin I and aldosterone involve recovery control in each individual sample, and the final results are always corrected for these recoveries. Plasma noradrenaline and adrenaline were determined by an enzymatic single-isotope derivative technique [41]. The volume of plasma analysed was $50 \mu \mathrm{l}$. The coefficient of variation calculated on the basis of duplicate determinations was $11 \%$ for adrenaline and $7 \%$ for noradrenaline.

\section{Statistical analysis}

Results are expressed as means $\pm 1 \mathrm{SD}$, data on hormones as means with ranges. All calculations were performed with commercially available programmes (BMDP, Statistical Software Inc, Los Angeles, Calif, USA). Equality of variances was ensured, if necessary after logarithmic transformation, before standard parametric statistics were applied. Individual groups were compared with others only when significant differences had been documented by ANOVA. RAAS and catecholamines were not normally distributed and therefore comparisons between groups of RAAS and catecholamines were performed non-parametrically (following a Kruskall-Wallis test). 
Table 1. Clinical characteristics and laboratory measurements of Type 1 (insulin-dependent) diabetic patients and normal control subjects

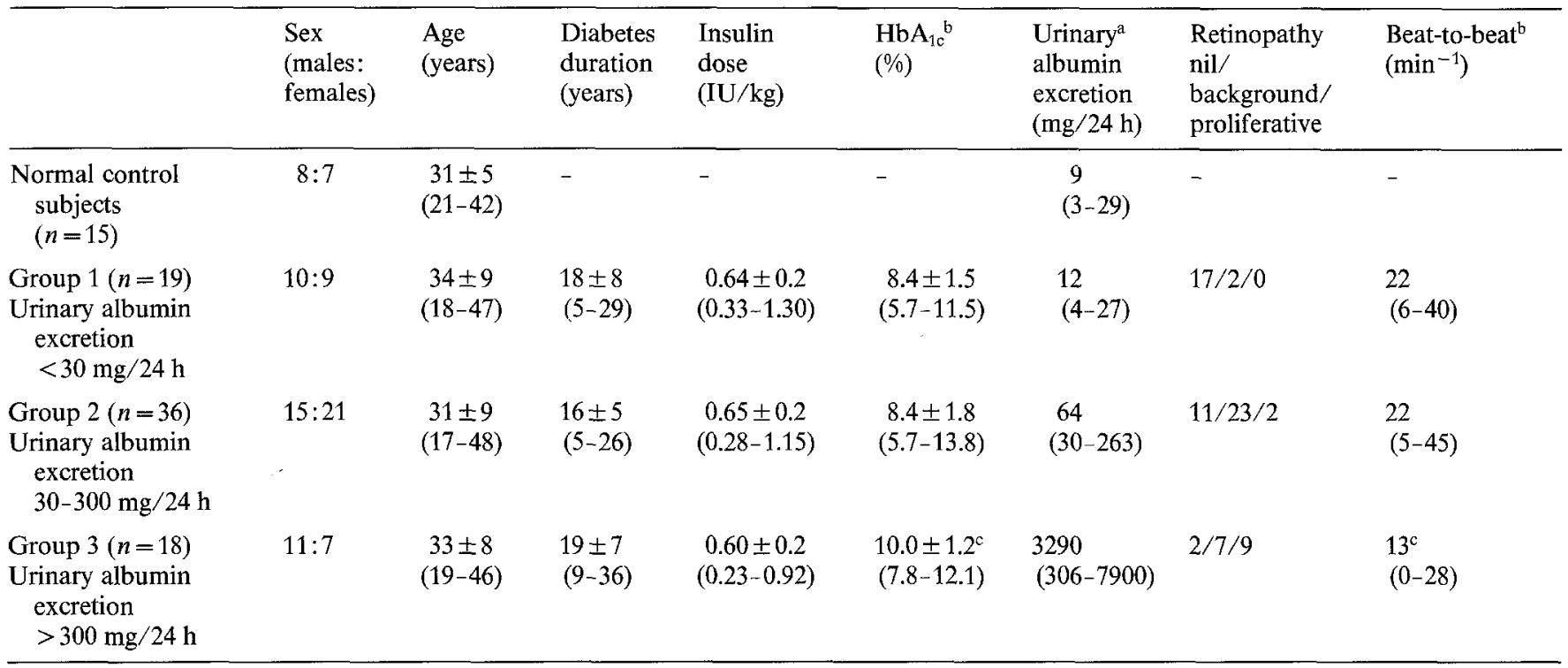

Values given as mean $\pm 1 \mathrm{SD}$, range in parenthesis. ${ }^{a}$ Median and range; ${ }^{b}$ differences between the groups, $p<0.02$ (one way analysis of variance); ${ }^{\mathrm{c}}$ significantly different from group 1 and $2, p<0.02$

Table 2. Exchangeable sodium, mean blood pressure and biochemical results in Type 1 (insulin-dependent) diabetic patients and normal controls subjects

\begin{tabular}{|c|c|c|c|c|c|c|}
\hline & $\begin{array}{l}\text { Mean }^{a} \\
\text { blood pressure } \\
(\mathrm{mmHg})\end{array}$ & $\begin{array}{l}\text { Exchangeable } \\
\text { sodium } \\
\left(\mathrm{meq} / 1.73 \mathrm{~m}^{2}\right)\end{array}$ & $\begin{array}{l}\mathrm{S}-\mathrm{Na} \\
(\mathrm{mmol} / \mathrm{l})\end{array}$ & $\begin{array}{l}\mathrm{S}-\mathrm{K} \\
(\mathrm{mmol} / \mathrm{l})\end{array}$ & $\begin{array}{l}\text { Urinary } \\
\text { sodium } \\
\text { excretion } \\
\text { (meq } / 24 \mathrm{~h})\end{array}$ & $\begin{array}{l}\text { Urinary } \\
\text { potassium } \\
\text { excretion } \\
(\text { meq } / 24 \mathrm{~h})\end{array}$ \\
\hline $\begin{array}{l}\text { Normal control subjects } \\
\qquad(n=15)\end{array}$ & $\begin{array}{c}95 \pm 11 \\
(80-120)\end{array}$ & $\begin{array}{c}2667 \pm 143 \\
(2450-2892)\end{array}$ & $\begin{array}{c}140 \pm 2 \\
(137-144)\end{array}$ & $\begin{array}{r}4.1 \pm 0.3 \\
(3.7-5.0)\end{array}$ & $\begin{array}{l}105 \pm 30 \\
(47-146)\end{array}$ & $\begin{array}{c}45 \pm 14 \\
(24-70)\end{array}$ \\
\hline $\begin{array}{l}\text { Group } 1(n=19) \\
\text { Urinary albumin excretion } \\
\quad<30 \mathrm{mg} / 24 \mathrm{~h}\end{array}$ & $\begin{array}{l}99 \pm 9 \\
(82-113)\end{array}$ & $\begin{array}{c}2844 \pm 322 \\
(2293-3497)\end{array}$ & $\begin{array}{l}141 \pm 3 \\
(135-146)\end{array}$ & $\begin{array}{r}4.2 \pm 0.3 \\
(3.5-4.9)\end{array}$ & $\begin{array}{l}105 \pm 40 \\
(40-172)\end{array}$ & $\begin{array}{c}54 \pm 23 \\
(13-103)\end{array}$ \\
\hline $\begin{array}{l}\text { Group } 2(n=36) \\
\text { Urinary albumin excretion } \\
\quad 30-300 \mathrm{mg} / 24 \mathrm{~h}\end{array}$ & $\begin{array}{l}102 \pm 11 \\
(82-123)\end{array}$ & $\begin{array}{r}2794 \pm 179^{b} \\
(2475-3184)\end{array}$ & $\begin{array}{c}140 \pm 3 \\
(134-145)\end{array}$ & $\begin{array}{c}4.3 \pm 0.4 \\
(3.6-5.1)\end{array}$ & $\begin{array}{l}122 \pm 41 \\
(57-212)\end{array}$ & $\begin{array}{r}52 \pm 15 \\
(16-88)\end{array}$ \\
\hline $\begin{array}{l}\text { Group } 3(n=18) \\
\text { Urinary albumin excretion } \\
\quad>300 \mathrm{mg} / 24 \mathrm{~h}\end{array}$ & $\begin{array}{l}121 \pm 12^{b, c} \\
(107-143)\end{array}$ & $\begin{array}{l}3041 \pm 434^{\mathrm{b}, \mathrm{c}} \\
(2229-4443)\end{array}$ & $\begin{array}{c}141 \pm 4 \\
(134-147)\end{array}$ & $\begin{array}{c}4.1 \pm 0.3 \\
(3.5-4.6)\end{array}$ & $\begin{array}{l}118 \pm 46 \\
(55-212)\end{array}$ & $\begin{array}{c}42 \pm 18 \\
(24-85)\end{array}$ \\
\hline
\end{tabular}

Mean $\pm 1 \mathrm{SD}$, range in parenthesis. Differences between the groups: ${ }^{a} p=0.003$ (one way analysis of variance); ${ }^{b}$ significantly different from normal control subjects; ${ }^{c}$ significantly different from group 2 patients

\section{Results}

The four groups were closely comparable for sex and age and, for the diabetic groups, diabetes duration and insulin dose (Table 1). Height, weight and surface area were similar in the four groups (data not shown). Long-term metabolic control $\left(\mathrm{HbA}_{1 \mathrm{c}}\right)$ was similar in groups 1 and 2, whereas the average metabolic status was worse in group 3 (Table 1). B-glucose on the days of study was higher in group 2 compared with the other groups (Table 3). Glucosuria was minor and similar in the diabetic groups (data not shown).

\section{Blood pressure and exchangeable sodium}

The mean blood pressure was correlated to the urinary albumin excretion in diabetic patients $(n=73, r=0.66$, $p<0.0001)$. Mean blood pressure was similar in control subjects and groups 1 and 2 but substantially higher in group 3 (Table 2). Exchangeable sodium was significantly higher in diabetic patients as compared to control subjects (Table 2), and higher in group 3 as compared to the other diabetic groups $(p<0.05)$. Exchangeable sodium was correlated to the mean blood pressure in diabetic patients $(n=70, r=0.41, p<$ 0.003 ). The correlation was also present within group 2 [patients with incipient nephropathy, $n=35, r=0.54$, $p<0.001$, (Fig.1)], but not in control subjects $(r=0.32$ ), group $1(r=0.14)$ or group 3 patients $(r=0.19)$ when analysed separately.

Sodium excretion, serum sodium and potassium were similar in the groups (Table 2). 
Table 3. Actual metabolic control, glomerular filtration rate (GFR), extracellular volume (ECV), plasma and blood volume in Type 1 (insulindependent) diabetic patients and normal control subjects

\begin{tabular}{|c|c|c|c|c|c|}
\hline & $\begin{array}{l}\text { Actual }^{\mathrm{a}} \\
\text { B-glucose } \\
(\mathrm{mmol} / 1)\end{array}$ & $\begin{array}{l}\text { Glomerular }^{a} \\
\text { filtration } \\
\text { rate }(\mathrm{GFR}) \\
\left(\mathrm{ml} / \mathrm{min} \times 1.73 \mathrm{~m}^{2}\right)\end{array}$ & $\begin{array}{l}\text { Extracellular }{ }^{a, \mathrm{c}} \\
\text { volume }(\mathrm{ECV}) \\
\left(\mathrm{ml} / 1.73 \mathrm{~m}^{2}\right)\end{array}$ & $\begin{array}{l}\text { Plasma volume } \\
\left(\mathrm{ml} / 1.73 \mathrm{~m}^{2}\right)\end{array}$ & $\begin{array}{l}\text { Blood volume } \\
\left(\mathrm{ml} / 1.73 \mathrm{~m}^{2}\right)\end{array}$ \\
\hline $\begin{array}{l}\text { Normal control subjects } \\
\quad(n=15)\end{array}$ & - & $\begin{array}{c}99 \pm 13 \\
(78-122)\end{array}$ & $\begin{array}{l}12589 \pm 2616 \\
(8527-19142)\end{array}$ & $\begin{array}{c}2592 \pm 272 \\
(2249-3063)\end{array}$ & $\begin{array}{c}4713 \pm 636 \\
(3903-5890)\end{array}$ \\
\hline $\begin{array}{l}\text { Group } 1(n=19) \\
\text { Urinary albumin excretion } \\
\quad<30 \mathrm{mg} / 24 \mathrm{~h}\end{array}$ & $\begin{array}{c}7.1 \pm 3.6 \\
(3.0-13.9)\end{array}$ & $\begin{array}{l}110 \pm 16^{b} \\
(86-143)\end{array}$ & $\begin{array}{c}14414 \pm 2747 \\
(10720-19764)\end{array}$ & $\begin{array}{c}2542 \pm 371 \\
(2037-3166)\end{array}$ & $\begin{array}{c}4581 \pm 790 \\
(3374-6220)\end{array}$ \\
\hline $\begin{array}{l}\text { Group } 2(n=36) \\
\text { Urinary albumin excretion } \\
\quad 30-300 \mathrm{mg} / 24 \mathrm{~h}\end{array}$ & $\begin{array}{c}9.3 \pm 3.0 \\
(3.4-18.7)\end{array}$ & $\begin{array}{l}107 \pm 19 \\
(69-150)\end{array}$ & $\begin{array}{l}14207 \pm 2750 \\
(8244-19439)\end{array}$ & $\begin{array}{c}2353 \pm 291 \\
(1722-2982)\end{array}$ & $\begin{array}{c}4255 \pm 577 \\
(2859-5627)\end{array}$ \\
\hline $\begin{array}{l}\text { Group } 3(n=18) \\
\text { Urinary albumin excretion } \\
\quad>300 \mathrm{mg} / 24 \mathrm{~h}\end{array}$ & $\begin{array}{c}7.1 \pm 3.8 \\
(3.6-18.0)\end{array}$ & $\begin{array}{r}79 \pm 33^{b} \\
(15-152)\end{array}$ & $\begin{array}{l}14615 \pm 2367^{b} \\
(9431-18944)\end{array}$ & $\begin{array}{r}2459 \pm 267 \\
(1970-2933)\end{array}$ & $\begin{array}{c}4278 \pm 399 \\
(3683-5039)\end{array}$ \\
\hline
\end{tabular}

Values given as mean $\pm 1 \mathrm{SD}$, range in parenthesis. Differences between the groups: ${ }^{\text {a }}$ (one way analysis of variance, $p<0.05$ ); ${ }^{b}$ significantly different compared to normal control patients, $p<0.05 ;{ }^{\mathrm{c}}$ control subjects versus all diabetic patients, $p<0.05$

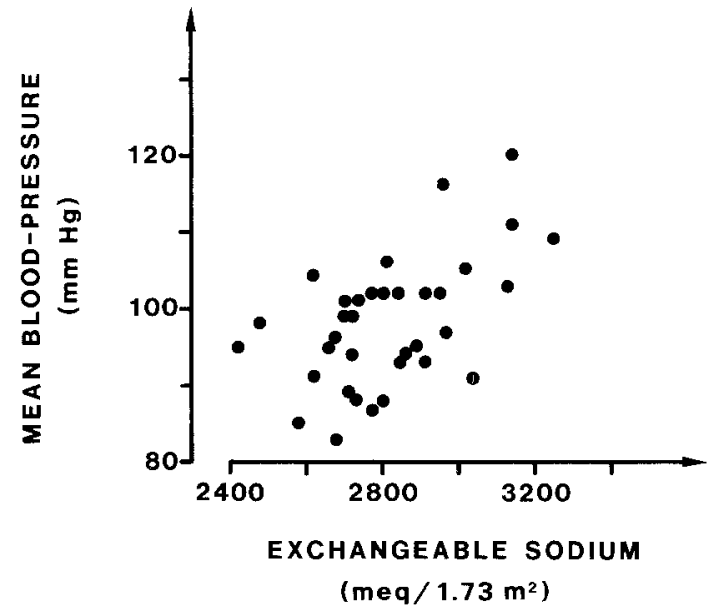

Fig. 1. Exchangeable sodium versus mean blood pressure in 35 Type 1 (insulin-dependent) diabetic patients with elevated urinary albumin excretion $(30-300 \mathrm{mg} / 24 \mathrm{~h}$, i. e. incipient diabetic nephropathy); $r=0.54, p<0.001$

\section{Kidney function and fluid volumes of the organism}

The glomerular filtration rate (GFR) was similar in groups 1 and 2 and significantly higher than in normal control subjects (Table 3). Group 3 patients with clinical nephropathy had significantly reduced GFR values $(p<0.05)$, the mean value being just within the normal range (Table 3). The extracellular volume (ECV) was higher in diabetic patients than in normal control subjects with no difference between the diabetic groups (Table 3). Plasma volume and blood volume were similar in control subjects and in diabetic patients (Table 3).

\section{Renin-angiotensin-aldosterone System (RAAS) (Table 4)}

Plasma concentrations of active renin (Fig. 2) and renin substrate (angiotensinogen) were similar in the three diabetic groups of patients and in control subjects (Table 4). A tendency to lower levels of plasma angiotensin $I$ in diabetic patients was observed $(p=0.06)$. Angiotensin II was significantly reduced in the diabetic patients $(p<0.001$, Fig. 3, Table 4$)$. This significant reduction was observed in the presence of a slightly elevated level of converting enzyme in the diabetic patients. Plasma aldosterone and angiotensin II were correlated in the patient groups $(n=67, r=0.30, p<$ $0.01)$. Plasma aldosterone tended to be lower in diabetic patients compared with control subjects $(p=0.22$, Table 4).

Including all diabetic patients, inverse correlations were found between mean blood pressure and aldosterone $(n=68, r=-0.24, p<0.05)$ and exchangeable sodium and aldosterone $(n=66, r=-0.36, p<0.002)$. Plasma inactive renin was similar in normal control subjects and in patients without complications, but significantly higher in groups 2 and 3. A direct correlation between the urinary albumin excretion as a measure of the degree of complications and inactive renin was found $(r=0.36, p<0.02)$.

\section{Catecholamines (Table 5)}

Plasma epinephrine was similar in diabetic patients and control subjects, whereas the norepinephrine level was reduced in group 2 and 3 patients (Table 4). No correlations were found between catecholamine levels and metabolic control, urinary albumin excretion, blood pressure or degree of autonomic neuropathy (beat-to-beat variation).

\section{Discussion}

This study has shown that exchangeable sodium is elevated in Type 1 diabetic patients free of complications 

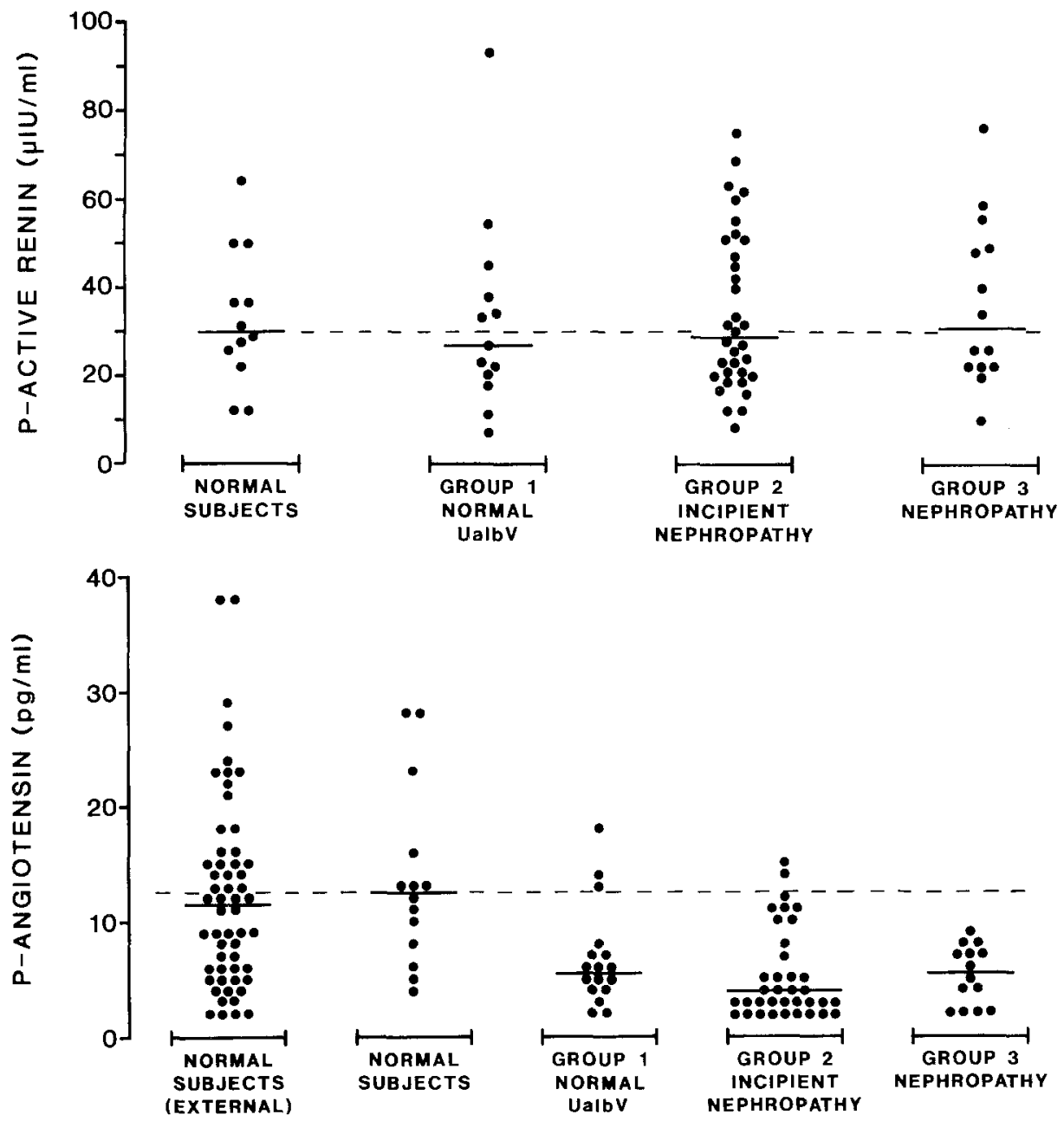

Fig. 2. Plasma active renin concentrations in Type 1 diabetic patients with different levels of urinary albumin excretion. Group 1: $<30 \mathrm{mg} / 24 \mathrm{~h}$ (normal); group 2: $30-300 \mathrm{mg} / 24 \mathrm{~h}$ (microalbuminuria); group $3:>300 \mathrm{mg} / 24 \mathrm{~h}$ (diabetic nephropathy)

Table 4. Renin-angiotensin-aldosterone system in Type 1 (insulin-dependent) diabetic patients and normal control subjects

\begin{tabular}{|c|c|c|c|c|}
\hline Plasma concentrations & $\begin{array}{l}\text { Normal control } \\
\text { subjects }(n=15)\end{array}$ & $\begin{array}{l}\text { Group } 1(n=19) \\
\text { Urinary albumin } \\
\text { excretion } \\
<30 \mathrm{mg} / 24 \mathrm{~h}\end{array}$ & $\begin{array}{l}\text { Group } 2(n=36) \\
\text { Urinary albumin } \\
\text { excretion } \\
30-300 \mathrm{mg} / 24 \mathrm{~h}\end{array}$ & $\begin{array}{l}\text { Group } 3(n=18) \\
\text { Urinary albumin } \\
\text { excretion } \\
>300 \mathrm{mg} / 24 \mathrm{~h}\end{array}$ \\
\hline Inactive $\operatorname{renin}^{\text {a }}(\mu \mathrm{IU} / \mathrm{ml})$ & $\begin{array}{l}129 \\
(49-231)\end{array}$ & $\begin{array}{l}134 \\
(51-308)\end{array}$ & $\begin{array}{l}232^{\mathrm{c}} \\
(26-790)\end{array}$ & $\begin{array}{l}356^{\mathrm{c}} \\
(87-1204)\end{array}$ \\
\hline Active renin $(\mu \mathrm{IU} / \mathrm{ml})$ & $\begin{array}{c}33 \\
(12-64)\end{array}$ & $\begin{array}{l}33 \\
(7-93)\end{array}$ & $\begin{array}{l}35 \\
(8-76)\end{array}$ & $\begin{array}{l}36 \\
(10-76)\end{array}$ \\
\hline Angiotensin I (pg/ml) & $\begin{array}{l}30 \\
(14-93)\end{array}$ & $\begin{array}{l}23 \\
(8-78)\end{array}$ & $\begin{array}{l}20 \\
(11-42)\end{array}$ & $\begin{array}{l}22 \\
(8-38)\end{array}$ \\
\hline Converting enzyme ${ }^{\mathrm{a}}$ (UCE) & $\begin{array}{l}25 \\
(15-46)\end{array}$ & $\begin{array}{l}29 \\
(15-60)\end{array}$ & $\begin{array}{l}33^{\mathrm{c}} \\
(19-56)\end{array}$ & $\begin{array}{l}30 \\
(15-62)\end{array}$ \\
\hline
\end{tabular}

Mean and range. Significance of the differences between the groups ${ }^{\mathrm{a}} p<0.05 ;{ }^{\mathrm{b}} p<0.001$ (Kruskall-Wallis test). ${ }^{\mathrm{c}}$ Significantly different from normal control patients

and even higher in patients with clinical nephropathy. These observations corroborate previous reports [15, 16], one of which further demonstrated a significant correlation between mean blood pressure and ex- changeable sodium in patients with diabetic nephropathy [16]. Our demonstration of this correlation also within a group of patients with microalbuminuria (Albustix negative urine and normal glomerular filtration 
Table 5. Catecholamines in Type 1 (insulin-dependent) diabetic patients and normal control subjects

\begin{tabular}{|c|c|c|c|c|}
\hline Plasma concentrations & $\begin{array}{l}\text { Normal control } \\
\text { subjects }(n=15)\end{array}$ & $\begin{array}{l}\text { Group } 1(n=19) \\
\text { Urinary albumin } \\
\text { excretion } \\
<30 \mathrm{mg} / 24 \mathrm{~h}\end{array}$ & $\begin{array}{l}\text { Group } 2(n=36) \\
\text { Urinary albumin } \\
\text { excretion } \\
30-300 \mathrm{mg} / 24 \mathrm{~h}\end{array}$ & $\begin{array}{l}\text { Group } 3(n=18) \\
\text { Urinary albumin } \\
\text { excretion } \\
>300 \mathrm{mg} / 24 \mathrm{~h}\end{array}$ \\
\hline Epinephrine (ng/ml) & $\begin{array}{l}0.2 \\
(0-0.05)\end{array}$ & $\begin{array}{l}0.03 \\
(0-0.14)\end{array}$ & $\begin{array}{l}0.02 \\
(0-0.05)\end{array}$ & $\begin{array}{l}0.02 \\
(0-0.10)\end{array}$ \\
\hline Norepinephrine $^{\mathrm{a}}(\mathrm{ng} / \mathrm{ml})$ & $\begin{array}{l}0.26 \\
(0.1-0.59)\end{array}$ & $\begin{array}{l}0.20 \\
(0.11-0.33)\end{array}$ & $\begin{array}{l}0.16^{b} \\
(0.07-0.50)\end{array}$ & $\begin{array}{l}0.15^{\mathrm{b}} \\
(0.01-0.40)\end{array}$ \\
\hline
\end{tabular}

Mean and range. Differences between the groups: ${ }^{a} p<0.001$ (one way analyses of variance); ${ }^{\mathrm{b}}$ significantly different from normal control subjects, $p<0.01$

rate) is new. These patients had normal blood pressure levels, the few truly hypertensive patients being excluded, but they are known to increase their blood pressure levels progressively [12]. Thus, the correlation of exchangeable sodium to mean blood pressure in this specific group supports the hypothesis that sodium retention may play a major role in the pathogenesis of this rise of blood pressure.

A number of important factors can be ruled out as causing the sodium retention observed. The sodium excretion was similar in all groups indicating a similar sodium intake during the days of investigation and the glomerular filtration rate was normal or supranormal except in a few group 3 patients. The long-term metabolic control was worse in group 3 and actual control on the day of study was worse in group 2. However, poor metabolic control with glucosuria is a sodiumloosing state during which exchangeable sodium is reduced [42].

Type 1 diabetic patients have peripheral hyperinsulinaemia due to peripheral administration of insulin, and hyperinsulinaemia causes increased tubular reabsorption of sodium [43]. This may explain the general increase in exchangeable sodium observed in the diabetic patients. To support this there is evidence that sodium retention in diabetes is mainly due to enhanced tubular reabsorption of sodium [44].

The effector components of the renin-angiotensinaldosterone system (RAAS) were either reduced (angiotensin II) or tended to be reduced (aldosterone). Mean blood pressure as well as exchangeable sodium were negatively correlated to aldosterone levels in diabetic patients. These observations suggest that neither the sodium retention in Type 1 diabetic patients nor the blood pressure rise in incipient and overt diabetic nephropathy is caused by hyperactivity of the RAAS as assessed in plasma, i.e. at the pre-receptor level.

The suppression of the RAAS was observed regardless of the presence or absence of diabetic complications (groups 1 to 3 ). This is in contrast to what was reported by Drury et al. [19], who suggested that secretion of renin might be impaired in diabetic patients with microvascular disease. We found similar levels of plasma renin concentration in the three groups. However, measurement of plasma renin concentration and activity in diabetic patients may not necessarily reflect changes in the effector components of the system. In our study angiotensin II and aldosterone either were, or tended to be, suppressed. Minor changes were also demonstrated in angiotensin I which tended to be reduced $(p=0.06)$. Angiotensin converting enzyme was elevated in diabetic patients, but plasma angiotensin II was significantly reduced. The dissociation between plasma renin and plasma angiotensin II concentration was not explained by differences in constitution of plasma between patients and groups, because our methods involved recovery control in each individual sample. The cause of the dissociation thus remains unclear.

Many factors will influence the plasma levels of the components of RAAS. All subjects were studied under standardised conditions after 1-h supine rest. The influence of age [45] and sodium intake [46] were ruled out in the present study due to the matching of the groups. The actual B-glucose level was higher in group 2 and long-term control worse in group 3. However, renin, angiotensin II and aldosterone have been described as unchanged (Sandahl Christiansen, personal communication) or elevated $[42,47]$ during episodes of poor metabolic control; and groups 2 and 3 generally presented the lower values of angiotensin II and aldosterone.

Plasma inactive renin currently considered to be a prohormone was normal in group 1, elevated in group 3 and correlated to the urinary albumin excretion. This supports previous observations by Luetscher et al., who suggested that increasing plasma inactive renin may predict the development of complications in diabetes [48].

The catecholamine levels were normal or reduced in diabetic patients as previously demonstrated $[25,26$, 49] and more so in groups 2 and 3. Thus, these substances could not cause the blood pressure rise. Again, the differences in metabolic control in the groups could not explain the observed differences $[42,49]$. The increased exchangeable mass of sodium, though unexplained by all other parameters measured in this study, was accompanied by a concomitant increase in the extracellular volume in accordance with previous observations [50]. This indicates that volume expansion may 
play an important role in the blood pressure rise observed in the development of diabetic nephropathy. Such a relation has been described in chronic glomerulonephritis with hypertension [51], but not in the present study, in patients with normal blood pressure and glomerular filtration rate. However, we observed a huge variation in extracellular volume within each group and could not demonstrate any differences between the diabetic groups nor could we find any correlations between mean blood pressure and extracellular volume.

In one study plasma volume was higher in normotensive diabetic patients [52]. In our study there were no differences in plasma and blood volume in control and diabetic patients as also described by others [16, 53].

The suppression of RAAS and catecholamines seems to rule out these parameters as the primary cause of sodium retention and hypertension in diabetes. Nevertheless, angiotensin-converting enzyme inhibition reduces blood pressure in Type 1 diabetic patients with nephropathy [54] and the RAAS may play a role if "inappropriately" reduced as previously suggested [19]. In the present study, plasma aldosterone was only insignificantly and thus perhaps inappropriately reduced in diabetic patients with sodium retention. Furthermore, possibly as a physiological response to the sodium retention [55], the vasopressor responsiveness to angiotensin II and norepinephrine is enhanced in Type 1 diabetes $[56,57]$. This could also play an important role when these systems are activated in the erect position and during physical exercise.

We conclude that sodium retention is present in all Type 1 diabetic patients, playing a major role in the blood pressure rise observed at the very early stages of diabetic renal disease. The effector components of RAAS, angiotensin II and aldosterone as well as the catecholamine levels are suppressed and cannot directly explain the sodium retention observed.

Acknowledgements. This work was supported by grants from $\mathbf{J}$. and O.Juhls Foundation, The Michaelsen Foundation, B. and M. Klein Foundation, The Danish Diabetes Association and The Danish Medical Research Council.

\section{References}

1. Deckert T, Poulsen JE, Larsen M (1978) Prognosis of diabetics with diabetes onset before the age of thirty-one. Diabetologia 14: 363-370

2. Wilson JL, Root HF, Marble A (1951) Diabetic nephropathy. A clinical syndrome. N Engl J Med 245: 513-517

3. Kussman JM, Goldstein HH, Gleason RE (1976) The clinical course of diabetic nephropathy. JAMA 236: 1861-1863

4. Andersen AR, Christiansen JS, Andersen JK, Kreiner S, Deckert $T$ (1983) Diabetic nephropathy in type 1 (insulin-dependent) diabetes. Diabetologia 25: 496-501

5. Borch-Johnsen K, Andersen PK, Deckert T (1985) The effect of proteinuria on relative mortality in type 1 (insulin-dependent) diabetes mellitus. Diabetologia 28: 590-596
6. Wiseman M, Viberti G, Mackintosh D, Jarrett RJ, Keen H (1984) Glycaemia, arterial pressure and microalbuminuria in Type 1 (insulin-dependent) diabetes mellitus. Diabetologia 26: 402-405

7. Mathiesen ER, Oxenbøll B, Johansen K, Svendsen PAa, Deckert $T$ (1984) Incipient nephropathy in Type 1 (insulin-dependent) diabetes. Diabetologia 26: 406-410

8. Mogensen CE, Christensen CK (1984) Predicting diabetic nephropathy in insulin-dependent patients. $N$ Engl J Med 311: 89-93

9. Feldt-Rasmussen B, Borch-Johnsen K, Mathiesen ER (1985) Hypertension as related to nephropathy. Early blood pressure changes. Hypertension 7 [Suppl 2]: 18-20

10. Parving H-H, Oxenbøll B, Svendsen PAa, Christiansen JS, Andersen AR (1982) Early detection of patients at risk of developing diabetic nephropathy. A longitudinal study of urinary albumin excretion. Acta Endocrinol 100: 550-555

11. Viberti GC, Hill RD, Jarrett RJ, Argyropoulos A, Mahmud U, Keen H (1982) Microalbuminuria as a predictor of clinical nephropathy in insulin-dependent diabetes mellitus. Lancet 1: $1430-1432$

12. Feldt-Rasmussen B, Mathiesen ER, Deckert T (1986) Effect of two years of strict metabolic control on progression of incipient nephropathy in insulin-dependent diabetes. Lancet 2: 1300-1304

13. Mogensen CE (1982) Long-term antihypertensive treatment inhibiting progression of diabetic nephropathy. $\mathrm{Br}$ Med $\mathbf{J} 285$ : 685-688

14. Parving H-H, Andersen AR, Smidt UM, Svendsen PAa (1983) Early aggressive antihypertensive treatment reduces rate of decline in kidney function in diabetic nephropathy. Lancet 1: 1175-1179

15. O'Hare JA, Ferris JB, Brady D, Twomey B, O'Sullivan DJ (1985) Exchangeable sodium and renin in hypertensive diabetic patients with and without nephropathy. Hypertension 7 [Suppl II]: 43-48

16. DeChatel R, Weidman P, Flammer J, Ziegler WH, Beretta-Piccoli C, Vetter W, Reubi FC (1977) Sodium, renin, aldosterone, catecholamines and blood pressure in diabetes mellitus. Kidney Int 12: $412-421$

17. Christlieb AR, Kaldang A, D'Elia JA (1976) Plasma renin activity and hypertension in diabetes mellitus. Diabetes 25:969-974

18. Burden AC, Thurston H (1979) Plasma renin activity in diabetes mellitus. Clin Sci 56: 255-259

19. Drury PL, Bodansky HJ, Oddie CJ, Edwards CRW (1984) Factors in the control of plasma renin activity and concentration in type 1 (insulin-dependent) diabetes. Clin Endocrinol 20: 607-618

20. Drury PL, Bodansky HJ, Oddie CJ, Cudworth AG, Edwards CRW (1982) Increased plasma renin activity in type 1 diabetes with microvascular disease. Clin Endocrinol 16: 453-461

21. Moss S, Oster JR, Perez GO, Katz FH, Vaamande CA (1978) Renin-Aldosterone responsiveness in uncomplicated juvenile-type diabetes mellitus. Horm Res 9: 130-136

22. Tuck ML, Sambhi MP, Levin L (1979) Hyporeninemyic hypoaldosteronism in diabetes mellitus. Diabetes 28: 237-241

23. Sunderlin FS, Anderson GH, Streeten DHP, Blumenthal SA (1981) The renin-angiotensin-aldosterone system in diabetic patients with hyperkalemia. Diabetes 30: 335-340

24. Ferris JB, Sullivan PA, Gonggrijp H, Cole M, O'Sullivan DJ (1982) Plasma angiotensin II and aldosterone in unselected diabetic patients. Clin Endocrinol 17: 261-269

25. Christensen NJ (1972) Plasma catecholamines in long-term diabetics with and without neuropathy and in hypophysectomized subjects. J Clin Invest 51: 779-787

26. Cryer PE, Silverberg AB, Santiago JV, Shah SD (1978) Plasma catecholamines in diabetes. Am J Med 64: 407-416

27. Feldt-Rasmussen B, Dinesen B, Deckert M (1985) Enzyme immuno assay - an improved determination of urinary albumin in diabetics with incipient nephropathy. Scand J Clin Lab Invest 45: $539-544$

28. Feldt-Rasmussen B, Mathiesen ER, Deckert T (1986) Kidney function during 12 months of strict metabolic control in insulindependent diabetic patients with incipient nephropathy. N Engl J Med 314: 665-670 
29. Svendsen PAa, Christiansen JS, Søegaard U, Welinder BA, Nerup J (1980) Rapid changes in chromatographically determined haemoglobin $\mathrm{A}_{\mathrm{Ac}}$ induced by short-term changes in glucose concentration. Diabetologia 19:130-136

30. Ewing DJ, Clarke BF (1982) Diagnosis and management of diabetic autonomic neuropathy. Br Med J 285: 916-918

31. Parving H-H, Gyntelberg F (1973) Transcapillary escape rate of albumin and plasma volume in essential hypertension. Cir Res 32: $643-651$

32. Evens RG, Baer L, Gill JR, Bartter FC (1968) Exchangeable sodium determinations by an isotope balance and a whole-body counter method. J Clin Endocrinol 28: 1645-1650

33. Brøchner-Mortensen J, Giese J, Rossing N (1969) Renal insulin clearance versus total plasma clearance of ${ }^{51} \mathrm{Cr}$-EDTA. Scand $\mathbf{J}$ Clin Lab 23: 301-305

34. Brøchner-Mortensen J (1980) A simple single injection method for determination of the extracellular fluid volume. Scand J Clin Lab 40: 567-573

35. Schiøler V, Damkjær Nielsen M, Kappelgaard AM, Giese J (1976) Partial purification of human renin substrate. Eur J Clin Invest 6: 229-240

36. Giese J, Damkjær Nielsen M, Kappelgaard AM (1981) Concentration of active and inactive renin in human plasma: concepts and methodology. In: Sambhi MP (ed) Heterogeneity of renin and renin substrate. Elsevier, Amsterdam, pp 205-213

37. Rasmussen S, Damkjær Nielsen M, Giese J (1981) Captopril combined with thiazide lowers renin substrate concentration: Implications for methodology in renin assays. Clin Sci 60:590-593

38. Kappelgaard AM, Damkjær Nielsen M, Giese J (1976) Measurement of angiotensin II in human plasma: technical modifications and practical experience. Clin Chem Acta 67: 299-306

39. Bruun NE, Ibsen H, Nielsen F, Damkjær Nielsen M, Mølbak AG, Hartling OJ (1986) Lack of effect of Nifedipine on counterregulatory mechanisms in essential hypertension. Hypertension 8: 655-661

40. Lieberman J (1975) Elevation of serum-converting enzyme (ACE) level in sarcoidosis. Am J Med 59: 365-372

41. Christensen NJ, Vestergaard P, Sørensen T, Rafaelsen OJ (1980) Cerebrospinal fluid adrenaline and noradrenaline in depressed patients. Acta Psychiatr Scand 61: 178-182

42. Ferris JB, O'Hare JA, Kelleher CCM, Sullivan PA, Cole MM, Ross HF, O'Sullivan DJ (1985) Diabetic control and the reninangiotensin system, catecholamines and blood pressure. Hypertension 7 [Suppl 2]: 58-63

43. DeFronzo RA (1981) The effect of insulin on renal sodium metabolism. Diabetologia 21: 165-171

44. Roland JM, O'Hare JP, Walters G, Corrall RJM (1986) Sodium retention in response to saline infusion in uncomplicated diabetes mellitus. Diabetes Res 3: 213-215

45. Tsunoda K, Abe K, Goto T, Yasujima M, Sato M, Omata K, Seino M, Yoshinaga K (1986) Effect of age on the renin-angioten- sin-aldosterone system in normal subjects: Simultaneous measurement of active and inactive renin, renin substrate and aldosterone in plasma. J Clin Endocrinol Metab 62: 384-389

46. Searly JE, Laragh JH (1974) A proposed cybernetic system for sodium and potassium homeostasis: coordination of aldosterone and intrarenal physical factors. Kidney Int 6: 281-290

47. Sullivan PA, Gonggrijp H, Crowley MJ, Ferris JB, O'Sullivan DJ (1980) Plasma angiotensin 2 and the control of diabetes mellitus. Clin Endocrinol 13: 387-392

48. Luetscher JA, Kraemer FB, Wilson DM, Schwartz HC, BryerAsh MB (1985) Increased plasma inactive renin in diabetes mellitus. N Engl J Med 312: 1412-1417

49. Christensen NJ (1973) Plasma norepinephrine and epinephrine in untreated diabetics during fasting and after insulin administration. Diabetes 23: 1-8

50. Brøchner-Mortensen J, Ditzel J (1982) Glomerular filtration rate and extracellular fluid volume in insulin-dependent patients with diabetes mellitus. Kidney Int 21: 696-698

51. Danielsen H, Pedersen EB, Christensen NJ (1986) Relationship of angiotensin II, aldosterone, arginine vasopressin, adrenaline and noradrenaline in plasma, blood and extracellular volumes to blood pressure in chronic glomerulonephritis. Eur J Clin Invest 16: $85-90$

52. Brøchner-Mortensen $\mathbf{J}$ (1973) Glomerular filtration rate and extracellular fluid volumes during normoglycemia and moderate hyperglycemia in diabetics. Scand J Clin Lab Invest 32: 311-316

53. O'Hare JA, Ferris JB, Twomey BM, Brady D, O'Sullivan DJ (1983) Essential hypertension and hypertension in diabetic patients without nephropathy. J Hypertension 1 [Suppl 2]: 200-203

54. Hommel E, Parving H-H, Mathiesen E, Edsberg B, Damkjær Nielsen M, Giese J (1986) Effect of captopril on kidney function in insulin-dependent diabetic patients with nephropathy. Br Med J 293: 467-470

55. Derek D (1984) In: The Hunger for Salt. Springer, Berlin Heidelberg New York Tokyo, p 123

56. Christlieb AR, Janka HU, Kraus B, Gleason RE, Icasas-Cabral EA, Arello LM, Cabral BV, Soluno A (1976) Vascular reactivity to angiotensin 2 and to norepinephrine in diabetic subjects. Diabetes 25: 268-274

57. Drury PL, Smith GM, Ferris JB (1984) Increased vasopressor responsiveness to angiotensin 2 in type 1 (insulin-dependent) diabetic patients without complications. Diabetologia 27:174-179

Received: 20 February 1987

and in revised form: 8 July 1987

Dr. Bo Feldt-Rasmussen

Steno Memorial Hospital

DK-2820 Gentofte

Denmark 